\title{
Vegetation and ecoregion analysis at Sipirok Botanic Gardens, South Tapanuli, North Sumatra, Indonesia
}

\author{
MUSTAID SIREGAR ${ }^{\star}$, DANANG W. PURNOMO, HARTUTININGSIH M-SIREGAR, JOKO RIDHO WITONO \\ Research Center for Plant Conservation and Botanic Gardens (Bogor Botanic Gardens), Indonesian Institute of Sciences. Jl. Ir. H. Juanda No. 13 Bogor \\ 16122, West Java, Indonesia. Tel./fax.: +62-251-8322-187, `email: mustaid_s@yahoo.co.id
}

Manuscript received: 10 April 2020. Revision accepted: 14 May 2020.

\begin{abstract}
Siregar M, Purnomo DW, Siregar HM, Witono JR. 2020. Vegetation and ecoregion analysis at Sipirok Botanic Gardens, South Tapanuli, North Sumatra, Indonesia. Biodiversitas 21: 2526-2535. Botanic Gardens is an ex-situ plant conservation area. Enrichment of plant collections of Botanic Gardens in Indonesia is based on ecoregion types. To find out the type of ecoregion, the existing vegetation, main native species should be known. The research aimed to analyze the existing vegetation and ecoregion type at Sipirok Botanic Gardens. Existing vegetation has been carried out using a separate plot method 20x20 m which is placed on purposively in nine locations considered to have different vegetation types, namely remnant forest, young secondary forests and shrubs, rubber plantation, and grasslands. Around 66 species belonged to 45 genera and 27 families were found in vascular plants $(\mathrm{dbh} \geq 10 \mathrm{~cm})$. There were 66 species of sapling belonged to 54 genera and 35 families, and 110 seedlings belonged to 87 genera and 50 families. The tree species that have the highest Importance Value Index are Ficus sumatrana (PU-1), Myristica fatua (PU-3), Hevea brasiliensis (PU-4 and PU-7), Artocarpus elasticus (PU-8), and Knema cinerea (PU-9). No trees were found in young secondary forest/shrub plots and grasslands. Unlike the species dominance index, the species diversity index and species equitability index are higher in natural forest plots. Beta diversity based on Jaccard similarity index and Whittaker's index shows a relatively different species composition among plots. Cluster analysis shows the tendency of grouping in 2 types of communities, namely: a) remnant forest communities, and b) secondary communities. The natural forest community is further divided into two communities consisting of remnant forest tree species and industrial/plantation plant species also secondary tree species. Secondary communities are also further divided into secondary forest communities and grasslands. Based on ecoregion analysis using previous publications, altitude, and diversity of plant species in the study site, Sipirok Botanic Gardens is a transitional zone of the Sumatran lowland rainforest and mountain rainforest.
\end{abstract}

Keywords: Ecoregion, North Sumatra, Sipirok Botanic Gardens, vegetation analysis

\section{INTRODUCTION}

Botanic gardens are ex-situ plant conservation areas that have a collection of plants documented and arranged based on taxonomic classification, bioregions, thematic, or a combination of these patterns for the purpose of conservation, research, education, tourism, and environmental services (Presidential Regulation Number 93 in 2011). The development of the botanic gardens begins with the preparation of the masterplan which guides the development in the short and long term. Existing data that includes biotic and abiotic data, as well as social and cultural community, is very much needed in the preparation of the masterplan.

According to Witono et al. (2012), development of new botanic garden in Indonesia is based on ecoregion concept. Ecoregion is relatively large units of land delineated to reflect the boundaries of natural communities of animal and plant species in their natural state (Kier et al. 2005). Based on the ecoregion map of Indonesia (Olson et al. 2001) modified by Witono et al. (2012), Indonesia consists of 47 ecoregion types, seven of which exist in Sumatra, namely: (i) Nias Islands' lowland rainforest on a series of western islands, (ii) northern Sumatra's mangrove forests on the east coast of Sumatra, (iii) Sumatran peat swamp forests in east coast of Sumatra, (iv) Sumatran freshwater swamp forests on the east coast of Sumatra, (v) Sumatran lowland rainforests spread in the lowlands of Sumatra, (vi) Sumatran mountain rain forest in the central part of Lake Toba, and (vii) tropical pine forests of Sumatra in the mountain regions of the west and southeast sides of Lake Toba.

Sipirok Botanic Gardens is botanic gardens that will be developed in Sumatra. The idea of developing this gardens originated from the concern of the South Tapanuli District Government due to the change of function of the Batangtoru forest and the degradation of the forest that became the habitat of the Tapanuli orangutan (Pongo tapanuliensis). Sipirok Botanic Gardens is expected to become a center for the conservation of native plants in South Tapanuli and Sumatra that are able to adapt to environmental conditions in the future. In Sipirok Botanic Gardens, there are four types of vegetation, namely: remnant forest, young secondary forest and shrubs, rubber gardens, and grasslands (Purnomo et al. 2018).

Vegetation and ecoregion analysis is important baseline study to maintain and/or establish both in situ and ex situ conservation areas. Previous studies of in situ conservation areas in Sumatra have been conducted such as Kerinci Seblat National Park (NP) (Gillison et al. 1996), Batang Gadis NP (Kartawinata et al. 2004), Bukit Duabelas NP (Rahmah et al. 2016), and Bukit Tiga Puluh National Park 
(Kuswanda and Barus 2019). Whereas in ex situ conservation areas in botanic gardens, vegetation, and ecoregion analysis are important step to design zone areas (Purnomo et al. 2018). According to Presidential Regulation Number 93 in 2011, at least three zones should be established, i.e. plant collection, welcoming, and management zones. Some botanic gardens in Indonesia have in-situ conservation area for native plants, such as Cibodas Botanic Gardens (Mutaqien and Zuhri 2011) and Megawati Soekarnoputri Botanic Gardens in North Sulawesi (Sugihartatmo et al. 2017).

It is necessary to designate natural habitat as an in situ conservation area in Sipirok Botanic Gardens. Protection of natural habitat is a better way to conserve and safeguard the species from tourists. Possible changes in the landscape and infrastructure during the development of the botanic gardens could potentially disrupt the habitat of native plants (Witono et al. 2020). This study aimed to analyze the vegetation and ecoregion types of the Sipirok Botanic Gardens as basic information for the development of infrastructure and plant collections in the future.

\section{MATERIALS AND METHODS}

\section{Study site}

This research was conducted in October 2018 in the Sipirok Botanic Gardens area, located in Kilangpapan and Sitorbis Village, Sipirok Sub-district, South Tapanuli District, North Sumatra Province, Indonesia (Figure 1). The area of about 88.15 ha is located at an altitude of about $765-915 \mathrm{~m}$ a.s.1. with topography ranging from slope to very steep. In this area, there are 2 types of soil, namely: entisol which are weathered ignimbrite volcanic sediments and organosols from weathering plants (PPTA 2000).
Based on the Köppen-Geiger climate classification, the Sipirok Botanic Gardens area has a climate type Af. The average annual rainfall is $2387 \mathrm{~mm}$ and the average annual temperature is $26.3^{\circ} \mathrm{C}$ in Sipirok. The highest rainfall occurred in December $(331.67 \mathrm{~mm})$ and the lowest in September $(89.43 \mathrm{~mm})$. Most rainy days occur in December (25 days) and rainy days are the least in July (9 days). The warmest temperatures occur in May (an average of $26.9^{\circ} \mathrm{C}$ ) and the lowest temperatures in November (an average of $26.0^{\circ} \mathrm{C}$ ) (Purnomo et al. 2018).

\section{Vegetation sampling}

Vegetation analysis was carried out using a separate plot method (Mueller-Dombois and Ellenberg 1974). A total of 9 plots (named 'PU' as main plot) of $20 \times 20 \mathrm{~m}$ were placed in each vegetation type with the following details: 5 PU of remaining forests (1,3,7,8,9 plots), 1 PU of secondary forests and shrubs (plot 2), 1 PU of gardens (plot 4 ), and 2 PU of grasslands (5,6 plots) (Figure 1). The main plot $(0.36 \mathrm{ha})$ has represented the area of vegetation in the Sipirok Botanic Gardens area. Each PU consists of four plots of $10 \times 10 \mathrm{~m}$ for tree-level sampling $(\mathrm{dbh} \geq 10 \mathrm{~cm})$. In a plot of $10 \times 10 \mathrm{~m}$, some plots of $5 \times 5 \mathrm{~m}$ were made for pole level sampling $(2 \mathrm{~cm} \leq \mathrm{dbh}<10 \mathrm{~cm})$. In some plots of $5 \times 5 \mathrm{~m}$, some plots of $2 \times 2 \mathrm{~m}$ were made for seedling and understorey $(\mathrm{dbh}<2 \mathrm{~cm})$. All species found in each plot were recorded by species name, number of individuals for each species, trunk diameter for trees and poles level sample as well as cover percentage for seedlings and understorey. Specimen vouchers for each species were made for identification. Identification was carried out by the Bogor Botanical Gardens Registration and Herbarium staff and partly at the Herbarium Bogoriense.

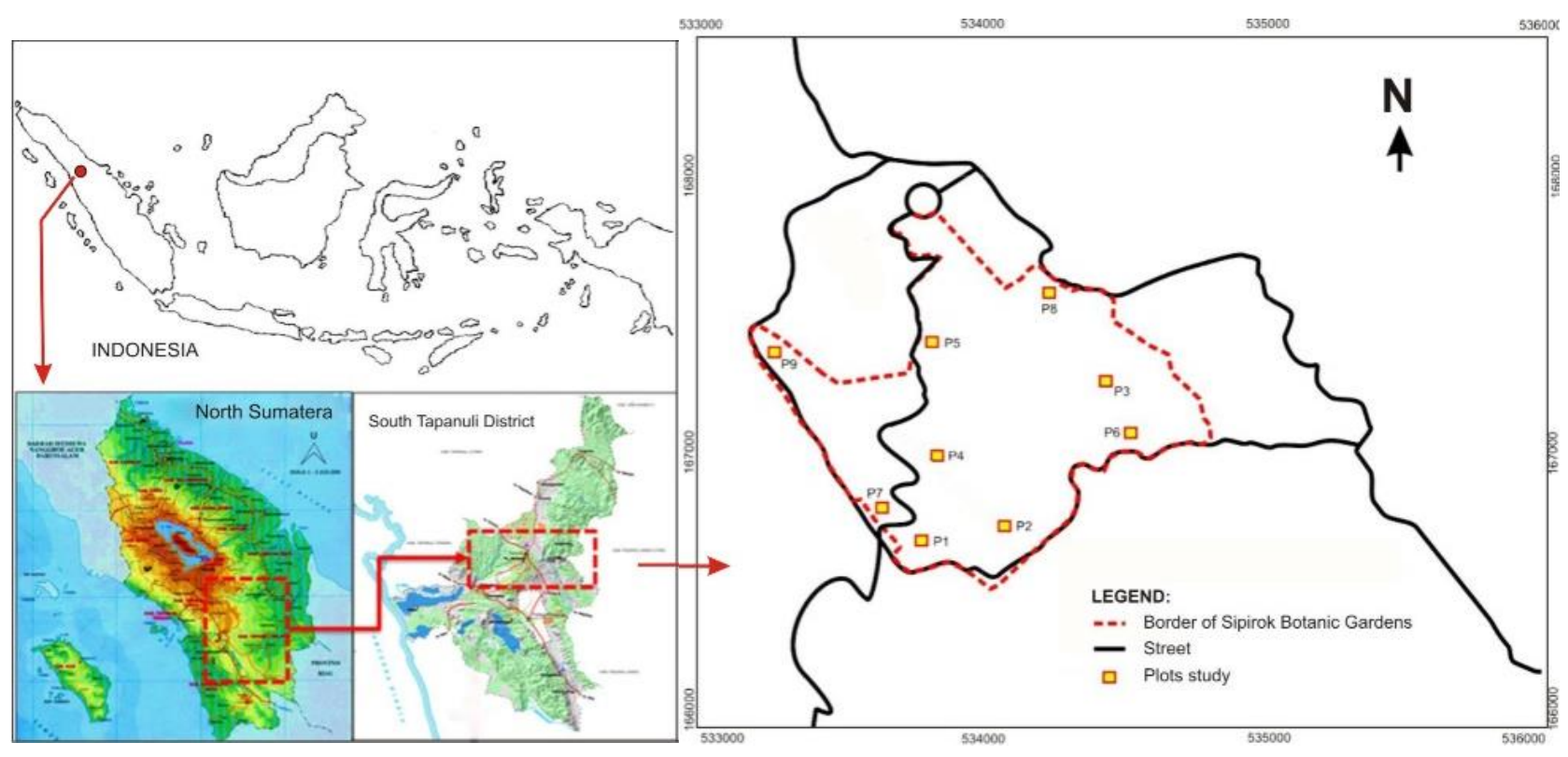

Figure 1. Study site in the Sipirok Botanic Gardens, in Kilangpapan and Sitorbis Villages, Sipirok Sub-district, South Tapanuli District, North Sumatra Province, Indonesia 


\section{Data analysis}

The data collected was then tabulated and analyzed to determine the value of density, relative density, frequency, relative frequency, dominance, relative dominance, and important value index (Mueller-Dombois and Ellenberg 1974). To analyze alpha diversity was calculated using the Shannon-Wiener diversity index, species dominance index, and evenness index, whereas to analyze beta diversity was calculated using the Whittaker diversity index and Jaccard species similarity index (Ludwig and Reynold 1988; Magurran 1988). Community types were determined based on the results of cluster analysis using Jaccard species similarity index based on the presence-absence of species in each main plot. All analyzes for alpha diversity, beta diversity, and cluster analysis were performed using the PAST (Paleontological Statistics) program version 3:04 (Hammer 2014).

\section{RESULTS AND DISCUSSION}

\section{Species composition}

Tree level plants $(\mathrm{dbh} \geq 10 \mathrm{~cm})$ found in 36 observation plots $(10 \times 10 \mathrm{~m})$ amounted to 66 species included in 45 genera and 27 families Tree species that have the highest Importance Value Index (IVI) in each main plot (PU) are Ficus sumatrana (PU-1), Mallotus peltatus (PU-2), Myristica fatua (PU-3), Hevea brasiliensis (PU-4 and PU7), Artocarpus elasticus (PU-8), and Knema cinerea (PU9). In young secondary forest plots and shrubs (PU-2) and grasslands (PU-5 and PU-6), no tree species with dbh $\geq 10$ $\mathrm{cm}$ were found (Table 1).

Table 1. Five species of trees based on the index of highest importance in each main plot

\begin{tabular}{|c|c|c|c|c|c|c|}
\hline No & Species & Family & $\begin{array}{l}\text { Density } \\
\text { ha }^{-1}\end{array}$ & $\begin{array}{l}\text { Basal area } \\
\left(\mathbf{m}^{2} \mathbf{h a}^{-1}\right)\end{array}$ & $\begin{array}{l}\text { Frequency } \\
(\%)\end{array}$ & $\begin{array}{l}\text { Importance } \\
\text { Value Index }\end{array}$ \\
\hline \multicolumn{7}{|c|}{ PU-1 } \\
\hline & Ficus sumatrana Miq. & Moraceae & 25 & 44.32 & 4.00 & 52.60 \\
\hline & Palaquium sp. & Sapotaceae & 100 & 5.48 & 12.00 & 32.92 \\
\hline & Palaquium obovatum (Griff.) Engl. & Sapotaceae & 50 & 10.79 & 8.00 & 26.59 \\
\hline & Canthium glabrum Blume & Rubiaceae & 75 & 2.52 & 12.00 & 26.08 \\
\hline & Knema sumatrana (Blume) W.J.de Wilde & Myristicaceae & 50 & 5.25 & 8.00 & 21.00 \\
\hline \multicolumn{7}{|c|}{ PU-2 } \\
\hline & Mallotus peltatus (Geiseler) Müll.Arg. & Euphorbiaceae & 50 & 0.39 & 50 & 147.39 \\
\hline & Mallotus paniculatus (Lam.) Müll.Arg. & Euphorbiaceae & 25 & 0.24 & 25 & 78.92 \\
\hline & Ficus padana Burm.f. & Moraceae & 25 & 0.20 & 25 & 73.69 \\
\hline \multicolumn{7}{|c|}{ PU-3 } \\
\hline & Myristica fatua Houtt. & Myristicaceae & 75 & 3.02 & 11.11 & 41.43 \\
\hline & Macaranga tanarius (L.) Müll.Arg. & Euphorbiaceae & 50 & 3.01 & 5.56 & 31.09 \\
\hline & Syzygium sp. & Myrtaceae & 50 & 2.61 & 5.56 & 28.93 \\
\hline & Ficus elliptica Kunth & Moraceae & 25 & 3.47 & 5.56 & 28.74 \\
\hline & Arenga pinnata (Wurmb) Merr. & Arecaceae & 25 & 1.46 & 5.56 & 18.08 \\
\hline \multicolumn{7}{|c|}{ PU-4 } \\
\hline PU-5 & Hevea brasiliensis (Willd. ex A.Juss.) Müll.Arg. & Euphorbiaceae & 750 & 14.84 & 100 & 300.00 \\
\hline \multicolumn{7}{|c|}{ PU-6 } \\
\hline \multicolumn{7}{|c|}{ PU-7 } \\
\hline & Hevea brasiliensis (Willd. ex A.Juss.) Müll.Arg. & Euphorbiaceae & 75 & 6.80 & 11.11 & 55.39 \\
\hline & Arenga pinnata (Wurmb) Merr. & Arecaceae & 75 & 5.83 & 11.11 & 51.21 \\
\hline & Palaquium obovatum (Griff.) Engl. & Sapotaceae & 25 & 3.90 & 5.56 & 27.35 \\
\hline & Turpinia sphaerocarpa Hassk. & Staphyleaceae & 50 & 0.78 & 11.11 & 24.47 \\
\hline & Macropanax undulatus (Wall. ex G.Don) Seem. & Araliaceae & 50 & 0.57 & 11.11 & 23.57 \\
\hline \multicolumn{7}{|c|}{ PU-8 } \\
\hline & Artocarpus elasticus Reinw. ex Blume & Moraceae & 75 & 20.43 & 15.79 & 71.82 \\
\hline & Arytera littoralis Blume & Sapindaceae & 75 & 1.89 & 15.79 & 35.31 \\
\hline & Symplocos racemosa Roxb. & Symplocaceae & 25 & 7.07 & 5.26 & 24.45 \\
\hline & Nothaphoebe sp. & Lauraceae & 50 & 1.14 & 10.53 & 23.30 \\
\hline \multirow{2}{*}{\multicolumn{7}{|c|}{ PU-9 }} \\
\hline & & & & & & \\
\hline & Knema cinerea Warb. & Myristicaceae & 50 & 8.53 & 5.00 & 33.37 \\
\hline & Styrax benzoin Dryand. & Styracaceae & 50 & 4.37 & 10.00 & 28.15 \\
\hline & Arenga pinnata (Wurmb) Merr. & Arecaceae & 50 & 5.80 & 5.00 & 26.67 \\
\hline & Syzygium papyraceum B.Hyland & Myrtaceae & 75 & 3.19 & 5.00 & 23.96 \\
\hline & Meliosma simplicifolia (Roxb.) Walp. & Sabiaceae & 50 & 2.52 & 10.00 & 23.60 \\
\hline
\end{tabular}


Table 2. Five species of poles based on the important value index in each main plot

\begin{tabular}{|c|c|c|c|c|c|c|}
\hline No & Species & Family & $\begin{array}{c}\text { Density } \\
\text { ha }^{-1}\end{array}$ & $\begin{array}{c}\text { Basal area } \\
\left(\mathrm{m}^{2} \mathbf{h a}^{-1}\right)\end{array}$ & $\begin{array}{c}\text { Frequency } \\
(\%)\end{array}$ & $\begin{array}{l}\text { Importance } \\
\text { Value Index }\end{array}$ \\
\hline \multicolumn{7}{|c|}{ PU-1 } \\
\hline & Castanopsis motleyana King & Fagaceae & 100 & 0.71 & 14.29 & 76.58 \\
\hline & Canthium glabrum Blume & Rubiaceae & 100 & 0.13 & 14.29 & 37.08 \\
\hline & Picrasma javanica Blume & Simaroubaceae & 100 & 0.30 & 14.29 & 49.02 \\
\hline & Sterculia rubiginosa Zoll. ex Miq. & Malvaceae & 100 & 0.15 & 14.29 & 38.41 \\
\hline & Cassine japonica (Franch. \& Sav.) Kuntze & Celastraceae & 100 & 0.13 & 14.29 & 37.51 \\
\hline \multicolumn{7}{|c|}{ PU-2 } \\
\hline & Homalanthus populneus (Geiseler) Pax & Euphorbiaceae & 1,100 & 2.40 & 16.67 & 86.34 \\
\hline & Mallotus peltatus (Geiseler) Müll.Arg. & Euphorbiaceae & 900 & 1.82 & 25.00 & 79.99 \\
\hline & Mallotus paniculatus (Lam.) Müll.Arg. & Euphorbiaceae & 500 & 2.06 & 25.00 & 70.51 \\
\hline & Breynia sp. & Phyllanthaceae & 300 & 0.52 & 8.33 & 25.46 \\
\hline & Nothaphoebe sp. & Lauraceae & 100 & 0.14 & 8.33 & 13.59 \\
\hline \multicolumn{7}{|c|}{ PU-3 } \\
\hline & Quercus sp. & Fagaceae & 400 & 0.78 & 4.17 & 32.42 \\
\hline & Nothaphoebe sp. & Lauraceae & 200 & 0.54 & 8.33 & 25.21 \\
\hline & Syzygium sp. & Myrtaceae & 200 & 0.54 & 8.33 & 25.21 \\
\hline & Ficus sinuata Thunb. & Moraceae & 100 & 0.64 & 4.17 & 19.43 \\
\hline & Acronychia pedunculata (L.) Miq. & Rutaceae & 100 & 0.50 & 4.17 & 16.95 \\
\hline \multicolumn{7}{|c|}{ PU-4 } \\
\hline \multicolumn{7}{|c|}{ PU-5 } \\
\hline & Eurya acuminata DC. & Pentaphylacaceae & 200 & 0.18 & 66.67 & 214.29 \\
\hline & Litsea sp. & Lauraceae & 100 & 0.04 & 33.33 & 85.71 \\
\hline \multicolumn{7}{|c|}{ PU-6 } \\
\hline \multicolumn{7}{|c|}{ PU-7 } \\
\hline & Macaranga tanarius (L.) Müll.Arg. & Euphorbiaceae & 300 & 0.88 & 11.11 & 41.32 \\
\hline & Nothaphoebe sp. & Lauraceae & 300 & 0.83 & 11.11 & 40.43 \\
\hline & Macropanax undulatus (Wall. ex G.Don) Seem. & Araliaceae & 200 & 1.04 & 5.56 & 33.90 \\
\hline & Shorea acuminata Dyer & Dipterocarpaceae & 200 & 0.64 & 11.11 & 32.15 \\
\hline & Homalanthus populneus (Geiseler) Pax & Euphorbiaceae & 200 & 0.21 & 11.11 & 24.51 \\
\hline \multicolumn{7}{|c|}{ PU-8 } \\
\hline & Arytera littoralis Blume & Sapindaceae & 300 & 0.42 & 18.75 & 45.60 \\
\hline & Coffea arabica $\mathrm{L}$. & Rubiaceae & 100 & 0.11 & 6.25 & 14.55 \\
\hline & Ficus sinuata Thunb. & Moraceae & 100 & 0.05 & 6.25 & 12.86 \\
\hline & Knema cinerea Warb. & Myristicaceae & 300 & 0.49 & 12.50 & 41.37 \\
\hline & Knema sp.1 & Myristicaceae & 300 & 0.63 & 6.25 & 38.73 \\
\hline \multicolumn{7}{|c|}{ PU-9 } \\
\hline & Pyrenaria sp. & Theaceae & 400 & 0.80 & 13.04 & 57.07 \\
\hline & Nothaphoebe sp. & Lauraceae & 300 & 0.19 & 8.70 & 27.28 \\
\hline & Syzygium acuminatum (Roxb.) Miq. & Myrtaceae & 200 & 0.19 & 8.70 & 23.16 \\
\hline & Cryptocarya ferrea Blume & Lauraceae & 100 & 0.26 & 4.35 & 17.34 \\
\hline & Daemonorops sp. & Arecaceae & 100 & 0.26 & 4.35 & 17.34 \\
\hline
\end{tabular}

Pole level plants $(2 \mathrm{~cm} \leq \mathrm{dbh}<10 \mathrm{~cm})$ found in 36 observation plots $\left(5 \times 5 \mathrm{~m}^{2}\right)$ amounted to 66 species included in 54 genera and 35 families. Pole species that have the highest IVI in each main plot (PU) are Castanopsis motleyana (PU-1), Homalanthus populneus (PU-2), Quercus sp. (PU-3), Eurya acuminata (PU-5), Macaranga tanarius (PU-7), Arytera littoralis (PU-8), and Pyrenaria sp. (PU-9). In the rubber plantation (PU-4) and grassland (PU-6) plots, no pole species were found (Table 2).

Seedlings and understorey $(\mathrm{dbh}<2 \mathrm{~cm})$ found in 36 observation plots $(2 \times 2 \mathrm{~m})$ of 110 species included in 87 genera and 50 families. Seedlings that have the highest IVI in each main plot are Orophea enterocarpa (PU-1), Etlingera megalocheilos (PU-2), Selaginella plana (PU-3), Clidemia hirta (PU-4), Etlingera elatior (PU-5), Bromus racemosus (PU-6), Cinnamomum sintoc (PU-7). Coffea arabica (PU-8), and Boesenbergia rotunda (PU-9) (Table 3).

The remaining forest in the Sipirok Botanic Gardens is generally filled with species that grow in old secondary forests or primary forests that have been disturbed, such as: Castanopsis motleyana, Canthium glabrum, Picrasma javanica, Sterculia rubiginosa, Cassine japonica, Quercus sp., Nothaphoebe sp., Syzygium sp., Ficus sinuata, Acronychia pedunculata, Arenga pinnata, Palaquium obovatum, Turpinia sphaerocarpa, Macropanax undulatus, Artocarpus elasticus, Arytera littoralis, Symplocos racemosa, Sterculia foetida, Knema cinerea, Styrax benzoin, Syzygium papyraceum and Meliosma simplicifolia (Table 1). These species also grow dominantly in the pole 
phase, such as Canthium glabrum, Nothaphoebe sp., Syzygium sp., Ficus sinuata, Acronychia pedunculata, Macropanax undulatus, and others (Table 2). This is an indication that the natural regeneration process of native plant species has been going well. Several species of pioneer trees, such as Macaranga tanarius, are found in the pole phase. Most of these species do not include commercial wood species and do not have high economic value. However, some Shorea acuminata (Dipterocarpaceae) individuals are still found in this location in the pole phase.

Table 3. The five main species of seedlings and understorey based on the magnitude of the important value index in each main plot

\begin{tabular}{|c|c|c|c|c|c|}
\hline No & Species & Family & $\begin{array}{c}\text { Crown Cover } \\
(\%)\end{array}$ & $\begin{array}{c}\text { Frequency } \\
(\%)\end{array}$ & $\begin{array}{l}\text { Importance } \\
\text { Value Index }\end{array}$ \\
\hline \multicolumn{6}{|c|}{ PU-1 } \\
\hline & Orophea enterocarpa Maingay ex Hook.f. \& Thomson & Annonaceae & 38.00 & 10.34 & 31.11 \\
\hline & Harpullia cupanioides Roxb. & Sapindaceae & 25.00 & 3.45 & 17.11 \\
\hline & Coffea arabica $\mathrm{L}$ & Rubiaceae & 12.00 & 6.90 & 13.45 \\
\hline & Canthium glabrum Blume & Rubiaceae & 7.00 & 6.90 & 10.72 \\
\hline & Cryptocarya murrayi F.Muell. & Lauraceae & 12.00 & 3.45 & 10.01 \\
\hline \multicolumn{6}{|c|}{ PU-2 } \\
\hline & Etlingera megalocheilos (Griff.) A.D.Poulsen & Zingiberaceae & 80.00 & 12.90 & 42.87 \\
\hline & Oplismenus compositus (L.) P.Beauv. & Poaceae & 50.00 & 6.45 & 25.18 \\
\hline & Nephrolepis cordifolia (L.) C. Presl & Nephrolepidaceae & 30.60 & 12.90 & 24.36 \\
\hline & Vernonia potamophila Klatt & Compositae & 40.00 & 3.23 & 18.21 \\
\hline & Bromus racemosus $\mathrm{L}$. & Poaceae & 20.00 & 6.45 & 13.94 \\
\hline \multicolumn{6}{|c|}{ PU-3 } \\
\hline & Selaginella plana (Desv. ex Poir.) Hieron. & Selaginellaceae & 125.00 & 19.05 & 71.79 \\
\hline & Pandanus sp. & Pandanaceae & 20.00 & 4.76 & 13.20 \\
\hline & Атотит sp. & Zingiberaceae & 10.00 & 4.76 & 8.98 \\
\hline & Etlingera elatior (Jack) R.M.Sm. & Zingiberaceae & 10.00 & 4.76 & 8.98 \\
\hline & Mucuna sp. & Leguminosae & 10.00 & 4.76 & 8.98 \\
\hline \multicolumn{6}{|c|}{ PU-4 } \\
\hline & Clidemia hirta (L.) D. Don & Melastomataceae & 95.00 & 9.76 & 40.65 \\
\hline & Spermacoce laevis Lam. & Rubiaceae & 58.00 & 7.32 & 26.18 \\
\hline & Sida rhombifolia $\mathrm{L}$ & Malvaceae & 40.00 & 2.44 & 15.45 \\
\hline & Crassocephalum crepidioides (Benth.) S.Moore & Compositae & 10.00 & 7.32 & 10.57 \\
\hline \multirow{2}{*}{\multicolumn{6}{|c|}{ PU-5 }} \\
\hline & & & & & \\
\hline & Etlingera elatior (Jack) R.M.Sm. & Zingiberaceae & 48.00 & 9.68 & 29.35 \\
\hline & Vernonia potamophila Klatt & Compositae & 37.00 & 12.90 & 28.07 \\
\hline & Nephrolepis cordifolia (L.) C. Presl & Nephrolepidaceae & 25.00 & 9.68 & 19.92 \\
\hline & Centrosema sp. & Leguminosae & 16.00 & 12.90 & 19.46 \\
\hline & Axonopus compressus (Sw.) P.Beauv. & Poaceae & 18.00 & 6.45 & 13.83 \\
\hline \multicolumn{6}{|c|}{ PU-6 } \\
\hline & Bromus racemosus $\mathrm{L}$. & Poaceae & 320.00 & 20.00 & 80.49 \\
\hline & Mucuna sp. & Leguminosae & 55.00 & 20.00 & 30.40 \\
\hline & Melastoma malabathricum $\mathrm{L}$. & Melastomataceae & 60.00 & 10.00 & 21.34 \\
\hline & Vernonia potamophila Klatt & Compositae & 18.00 & 15.00 & 18.40 \\
\hline & Rhodomyrtus tomentosa (Aiton) Hassk. & Myrtaceae & 23.00 & 10.00 & 14.35 \\
\hline \multicolumn{6}{|c|}{ PU-7 } \\
\hline & Cinnamomum sintoc Blume & Lauraceae & 21.00 & 11.11 & 24.24 \\
\hline & Nephrolepis cordifolia (L.) C. Presl & Nephrolepidaceae & 15.00 & 14.81 & 24.19 \\
\hline & Coffea arabica $\mathrm{L}$. & Rubiaceae & 18.00 & 11.11 & 22.36 \\
\hline & Macaranga tanarius (L.) Müll.Arg. & Euphorbiaceae & 20.00 & 7.41 & 19.91 \\
\hline & Clidemia hirta (L.) D. Don & Melastomataceae & 17.00 & 7.41 & 18.03 \\
\hline \multicolumn{6}{|c|}{ PU-8 } \\
\hline & Coffea arabica $\mathrm{L}$ & Rubiaceae & 41.00 & 14.29 & 33.27 \\
\hline & Asystasia gangetica $(\mathrm{L}$.$) T.Anderson$ & Acanthaceae & 28.00 & 10.71 & 23.68 \\
\hline & Diplazium esculentum (Retz.) Sw. & Athyriaceae & 30.00 & 3.57 & 17.46 \\
\hline & Clidemia hirta (L.) D. Don & Melastomataceae & 11.00 & 10.71 & 15.81 \\
\hline & Dracaena angustifolia (Medik.) Roxb. & Asparagaceae & 12.00 & 7.14 & 12.70 \\
\hline \multicolumn{6}{|c|}{ PU-9 } \\
\hline & Boesenbergia rotunda (L.) Mansf. & Zingiberaceae & 110.00 & 10.00 & 43.95 \\
\hline & Coffea arabica $\mathrm{L}$. & Rubiaceae & 27.00 & 13.33 & 21.67 \\
\hline & Clidemia hirta (L.) D. Don & Melastomataceae & 15.00 & 13.33 & 17.96 \\
\hline & Suregada glomerulata (Blume) Baill. & Euphorbiaceae & 40.00 & 3.33 & 15.68 \\
\hline & Uvaria rufa Blume & Annonaceae & 20.00 & 6.67 & 12.84 \\
\hline
\end{tabular}


One species of introduction tree that is found and grows extensively in the remaining forest is Hevea brasiliensis. This species was cultivated in several locations by the community before the area was designated as Sipirok Botanic Gardens (Irwansah Harahap 2018. pers. Com.). H. brasiliensis is a species of estate crop originating from Brazil and has adapted to environmental conditions and grows widely in the Sipirok Botanic Gardens. At the location of the remaining forests, there are several species of plants that have economic value both native species, such as: Styrax benzoin and Arenga pinnata, and introduced species, such as Coffea arabica.

The density of trees in the 5 main plots of remaining forest (PU-1, PU-3, PU-7, PU-8, PU-9) is 475-675 ha-1 trees with an average of $565 \mathrm{ha}^{-1}$ trees. The base area is 18.82-99.04 $\mathrm{m}^{2} \mathrm{ha}^{-1}$ with an average of $46.50 \mathrm{~m}^{2} \mathrm{ha}^{-1}$. Based on several research results, forests in Sumatra have a density range of 414-687 ha-1 trees with an average of 542 $\mathrm{ha}^{-1}$ trees, and a range of basal areas of 22.9-41.55 $\mathrm{m}^{2} \mathrm{ha}^{-1}$ with an average of $28.46 \mathrm{~m}^{2} \mathrm{ha}^{-1}$ (Mirmanto et al. 1992; Sambas and Siregar 1999; Kartawinata et al. 2004; Sambas and Siregar 2004; Priatna et al. 2006; Samsoedin and Heriyanto 2010; Rahmah et al. 2016). The vegetation of remaining forest within the Sipirok Botanic Gardens area is relatively good compare to the level of tree density and area of the base area (Table 4). Tree species that have dbh $>50 \mathrm{~cm}$ in PU-1 are Ficus sumatrana $(150.2 \mathrm{~cm})$, Alstonia spectabilis $(66.2 \mathrm{~cm})$, Castanopsis motleyana $(65.9 \mathrm{~cm})$ and Palaquium obovatum $(52.5 \mathrm{~cm})$. In PU-8, Artocarpus elasticus $(66.5 \mathrm{~cm})$, Symplocos racemosa $(60.0 \mathrm{~cm})$, Artocarpus elasticus $(59.5 \mathrm{~cm})$, Sterculia foetida $(51.6 \mathrm{~cm})$, and Dysoxylum alliaceum $(50.0 \mathrm{~cm})$. Only one tree which is found in PU-9 that is Knema cinerea $(57.0 \mathrm{~cm})$. In PU-3 and PU-7, there is no trees that have $\mathrm{dbh}>50 \mathrm{~cm}$. The largest tree with dbh of $42.0 \mathrm{~cm}$ in PU-3 is Ficus elliptica. The largest tree with $\mathrm{dbh}$ of $44.6 \mathrm{~cm}$ in PU-7 is Palaquium obovatum.
In young secondary forest vegetation types and shrubs (PU 2), tree species are dominated by Mallotus peltatus, $M$. paniculatus, and Ficus padana. These species are native plants of South Tapanuli (www.theplantlist.org 2020). At the pole level, Mallotus peltatus and M. paniculatus are still classified as the main species based on their importance, but the most abundant poles species are Homalanthus populneus (1100 trees ha-1) (Table 2). H. populneus, Breynia sp., and Nothaphoebe sp. which are native species of South Tapanuli do not grow in the tree phase, but $H$. populneus is expected to dominate the tree level in the next succession phase. The seedling and understorey phases are dominated by pioneer species that grow in the early phases of ecological successions, such as Etlingera megalocheilos, Oplismenus compositus, Nephrolepis cordifolia, Vernonia potamophila, and Bromus racemosus.

In terms of rubber plantation type (PU 4), Hevea brasiliensis is the only species found in this area. This means that the maintenance of the rubber tree is carried out intensively by the manager by controlling other species of trees and pole phase rubber plants. This is indicated by the absence of rubber plants in the pole phase at that location. The seedling and understorey phases are dominated by pioneer species that grow in the early phases of ecological successions, such as: Clidemia hirta, Spermacoce laevis, Sida rhombifolia, Crassocephalum crepidioides, and Asystasia gangetica.

In terms of grassland vegetation types (PU 5 and 6), there are 2 species of pole, namely Eurya acuminata and Litsea sp. The dominant species of seedlings and understorey are shrubs (Melastoma malabathricum, Vernonia potamophila, Rhodomyrtus tomentosa), herbs (Etlingera elatior, Axonopus compressus, Bromus racemosus, and Nephrolepis cordifolia), and liana (Mucuna sp.). Ecological succession has begun to take place with the presence of these two species of poles which are categorized as shrubs to small trees.

Table 4. Comparison of the density and basal area of trees $(\mathrm{dbh} \geq 10 \mathrm{~cm})$ in the remaining forest vegetation in the Sipirok Botanic Gardens with some forest plots in Sumatra

\begin{tabular}{|c|c|c|}
\hline Location & $\begin{array}{l}\text { Density } \\
\text { ha }^{-1}\end{array}$ & $\begin{array}{c}\text { Basal Area } \\
\left(\mathbf{m}^{2} \mathbf{h a}^{-1}\right)\end{array}$ \\
\hline \multicolumn{3}{|l|}{ Sipirok Botanic Gardens: } \\
\hline -PU-1 - - n & 650 & 99.04 \\
\hline -PU-3 & 525 & 18.82 \\
\hline -PU-7 & 500 & 23.22 \\
\hline -PU-8 & 475 & 50.77 \\
\hline -PU-9 & 675 & 40.68 \\
\hline Ulu Talo Bengkulu (Mirmanto et al. 1992) & 528 & 32.42 \\
\hline Air Putih Bengkulu (Mirmanto et al. 1992) & 554 & 23.11 \\
\hline Mt. Muncung Singkep (Sambas and Siregar 1999) & 453 & 22.90 \\
\hline Batang Gadis National Park (Kartawinata et al. 2004) & 583 & 40.56 \\
\hline Ketambe, Gunung Leuser National Park (Sambas and Siregar 2004) & 546 & 30.76 \\
\hline Ketambe, Gunung Leuser National Park (Priatna et al. 2006) & 573 & 27.68 \\
\hline Gunung Leuser National Park (Samsoedin and Heriyanto 2010) & 687 & 24.52 \\
\hline Bukit Dua Belas National Park (Rahmah et al. 2016) & 414 & 25.71 \\
\hline
\end{tabular}




\section{Diversity index}

Tree level alpha diversity calculated based on ShannonWiener diversity index $\left(\mathrm{H}^{\prime}\right)$ using species abundance data obtained the highest value at PU-3 $(\mathrm{H}=2.756)$, followed by PU-9 $(\mathrm{H}=2.712)$, PU-1 ( $\mathrm{H}=2.705)$, PU-7 $(\mathrm{H}=2.528)$, PU-8 $(\mathrm{H}=2.525)$ and PU-2 $(\mathrm{H}=1.040)$. Based on the Shannon-Wiener diversity index value criteria (Odum and Barrett 2005), species diversity in the remaining forests is classified as moderate $\left(1<\mathrm{H}^{\prime} \leq 3\right)$. According to Gaines et al. (1999), species diversity indices consider the species abundance and wealth generally ranging 1.5-3.5 and rarely reaching 4.5. This means that PU-2, which is a young secondary forest and shrub, is classified into species that is very low in tree species diversity. The average index value of tree species using species abundance data shows that the tree species in the remaining forest plots and secondary forests are high with values close to 1 . The highest value is obtained at PU-9 $(\mathrm{E}=0.978)$, followed by PU-3 $(\mathrm{E}=$ 0.973), PU-7 (E = 0.958), PU-8 ( $\mathrm{E}=0.957)$, PU-1 $(\mathrm{E}=$ $0.955)$ and PU-2 (0.946). According to Kendeigh (1980), an evenness index of species close to one indicates that the populations in the community are evenly distributed. If the equity index is close to zero, the populations in the community are unevenly distributed.

If all species (trees, poles, seedlings, and understory) are analyzed based on their presence in each plot, the value of species diversity in the remaining forest plots (PU-1, PU-3, PU-7, PU-8, PU-9), secondary forests and shrubs (PU-2) and rubber plantations (PU-4) are classified as high (H> 3), while in the meadow plots (PU-5, PU-6) are classified as moderate (Figure 2a ). It appears that the level of species diversity increases with the level of vegetation development. Remaining natural forests (PU-1, PU-3, PU7, PU-8, and PU-9) have a higher species diversity index than rubber plantations (PU-4), young secondary forests and shrubs (PU-2) and the lowest one is in pasture plot (PU-5, PU-6).

The dominance index of all species shows the opposite of the species diversity index. Remnant forest plots show lower species dominance index than secondary forest plots and shrubs (PU-2), rubber plantations (PU-4), and grasslands (PU-5, PU-6) (Figure 2b). The evenness index of species is directly proportional to the species diversity index which appears higher in remnant forest plots and the lowest is in grassland vegetation plots (Figure 2c). Thus, the species wealth index is directly proportional to the species diversity index and the evenness index of the species and inversely proportional to the species dominance index. A common phenomenon in tropical rainforests is the more species are found, the more index value of species diversity will be (Barbour et al. 1987). The high dominance index value on PU-6 (Figure 2b) shows the presence of a very dominant species, namely Bromus racemosus (Table 3). According to Smith (1977), in general, the dominant species is the species that can utilize the environment where it grows efficiently. However, the level of vegetation stability in communities dominated by few species is generally low such as PU-6 (Figure 2c). This is different from vegetation that has a high degree of diversity and evenness of species, or there are no species that is very dominant, so the stability of the community is relatively high on environmental changes (Barbour et al. 1987; Odum and Barrett 2005).

Beta diversity calculated using the Jaccard species similarity index (ISj) generally shows relatively low values. Two communities are considered to have large species similarity if they have a Jaccard similarity index > 50\% (Mueller-Dombois and Ellenberg 1974). The highest species similarity is found in the pairs of PU-4 and PU-5 with a species similarity index value of $24.2 \%$, followed by PU-2 and PU-5 (ISj = 21.2\%), PU-7 and PU-9 (ISj = $18.8 \%$ ), PU-3 and PU-9 (ISj = 17.9\%), PU-8 and PU-9 $(\mathrm{ISj}=16.4 \%)$ and the lowest is between pasture plots (PU6) and remaining forest (PU-7, PU-8 and PU-9) without any species at all $(\mathrm{ISj}=0.0 \%)$ (Table 5). These results indicate the tendency of the main plot with the same vegetation type to have a higher species similarity value compares to the main plot that has a different vegetation type.

Based on the results of cluster analysis of species presence data using the Jaccard formula in each main plot, there is a tendency for grouping into 2 clusters, namely: a) Remnant forest vegetation (PU-1, PU-3, PU-7, PU-8, and PU-9), and b) other vegetation. The remaining forest community is further divided into 2 sub-clusters, namely PU-8 and PU-1 which are dominated by native tree species, such as Ficus sumatrana, Palaquium sp., Artocarpus elasticus, and Arytera littoralis and PU-3, PU-7, PU-9 dominated by industrial/plantation tree species and secondary tree species such as Myristica fatua, Macaranga tanarius, Hevea brasiliensis, Arenga pinnata, Knema cinerea, and Styrax benzoin. Cluster 2 of other communities are also divided into 2 sub-clusters, namely subcluster 1 consisting of young secondary forest vegetation and shrubs (PU-2), rubber gardens (PU-4) and grasslands (PU-5); and subcluster 2 consisting of grassland vegetation (PU-6) (Figure 3).

Based on the results of the analysis with the Whittaker beta diversity index (Whittaker's index), the change in species composition from one location to another is relatively large, as seen from the value that approaches 1 . The value of the beta diversity index ranges from $0-1$. If beta diversity $=0$, then the change in species composition from location 1 to location 2 is small or there is no change. Conversely, if the understanding of beta $=1$, then there is a change in the composition of species that is real from location 1 to location 2 (Tothmeresz 2013). The smallest Whittaker's index value or location that is relatively similar is found in the pairs of PU-4 and PU-5 (0.610), while the highest value (1.0) or the main plots that have large composition changes are between PU-6 which is a meadow with natural forest plots on PU-1, PU-7, PU-8 and PU-9 (Table 6).

\section{Ecoregion}

Based on the ecoregion map of Indonesia (Olson et al. 2001) modified by Witono et al. (2012), there are at least 7 types of ecoregions in North Sumatra. There are different opinions of experts regarding the upper boundary of the lowland rainforest and the lower limit of the sub-montane 
rainforest. The lower limit of the sub-montane region is at an altitude of about 750-1200 $\mathrm{m}$ above sea level (Whitmore 1984), 750-1000 $\mathrm{m}$ above sea level (van Steenis 2006; Kartawinata 2013), and $1200 \mathrm{~m}$ above sea level (Whitten et al. 1984). The temperature and cloud level are the main determinants of the boundaries of the two forest zones (Whitten et al. 1984). The difference is also influenced by the location and isolation of the mountain. In isolated small mountains and outermost mountains of the main range, the upper limit of lowland rainforest is around 700-900 m above sea level. In the lower mountain rainforests, the limit is around 1200-1600 $\mathrm{m}$ above sea level. In the main ridge, the range of boundaries is higher, each boundary is around 1200-1500 m above sea level and 1800-2300 m above sea level. This phenomenon is known as the 'Massenerhebung' effect (Grubb 1971).

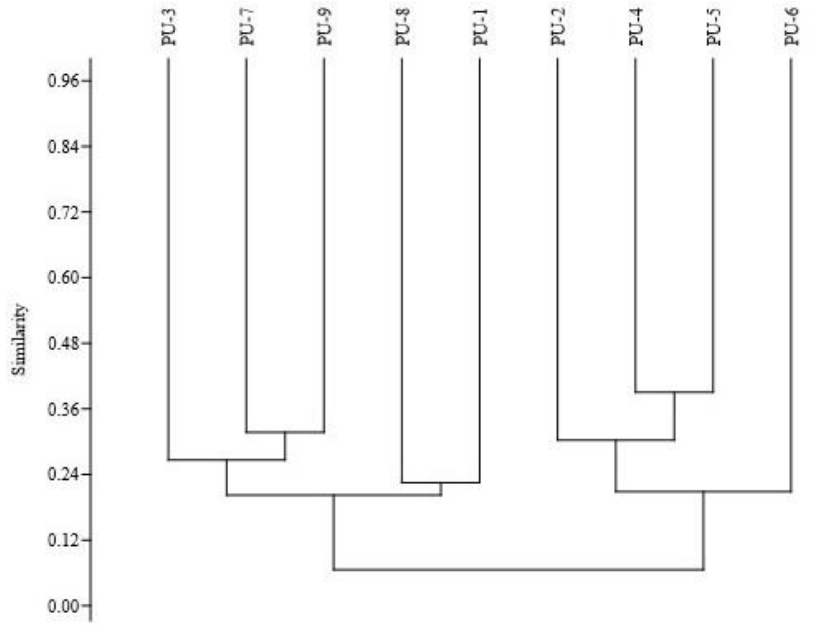

Figure 3. Analysis of 9 main plot (PU) clusters based on species presence

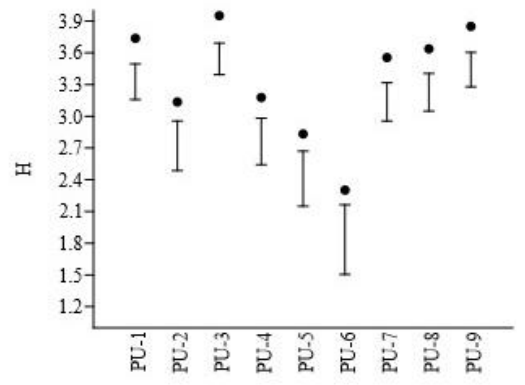

A

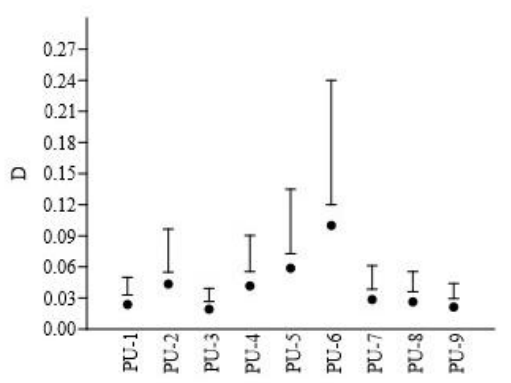

B

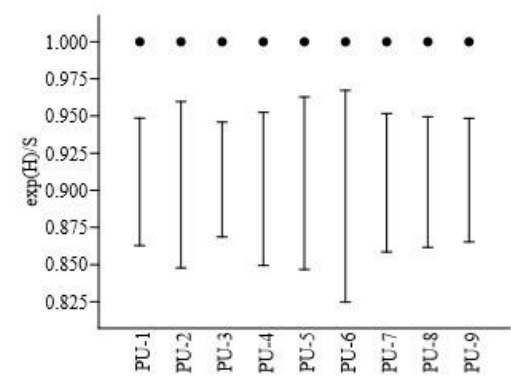

C

Figure 2. Diversity index, dominance index and evenness index of all species (trees, poles, seedlings) based on their presence in each plot (presence-absence)

Table 5. Jaccard species similarity index values between main plot pairs

\begin{tabular}{lllllllll}
\hline & PU-1 & PU-2 & PU-3 & PU-4 & PU-5 & PU-6 & PU-7 & PU-8 \\
\hline PU-2 & 0.0156 & & & & & & & \\
PU-3 & 0.0682 & 0.0135 & & & & & & \\
PU-4 & 0.0154 & 0.1463 & 0.0270 & & & & \\
PU-5 & 0.0172 & 0.2121 & 0.0455 & 0.2424 & & & \\
PU-6 & 0.0000 & 0.1379 & 0.0164 & 0.1333 & 0.0800 & & \\
PU-7 & 0.1159 & 0.0943 & 0.1299 & 0.0727 & 0.1304 & 0.0000 & 0.1061 & 0.1884 \\
PU-8 & 0.1268 & 0.0339 & 0.0843 & 0.0690 & 0.0784 & 0.0000 & 0.0000 & 0.1644 \\
PU-9 & 0.1410 & 0.0145 & 0.1786 & 0.0290 & 0.0323 & 0.000 & \\
\hline
\end{tabular}

Table 6. Beta diversity index values based on Whittaker's index formula between main plot pairs

\begin{tabular}{lllllllll}
\hline & PU-1 & PU-2 & PU-3 & PU-4 & PU-5 & PU-6 & PU-7 & PU-8 \\
\hline PU-2 & 0.9692 & & & & & & & \\
PU-3 & 0.8723 & 0.9733 & & & & & & \\
PU-4 & 0.9697 & 0.7447 & 0.9474 & & & & \\
PU-5 & 0.9661 & 0.6500 & 0.9130 & 0.6098 & & & \\
PU-6 & 1.0000 & 0.7576 & 0.9677 & 0.7647 & 0.8519 & & \\
PU-7 & 0.7922 & 0.8276 & 0.7701 & 0.8644 & 0.7692 & 1.0000 & 0.8082 & 0.7177 \\
PU-8 & 0.7750 & 0.9344 & 0.8444 & 0.8710 & 0.8546 & 1.0000 & 0.6829 & \\
PU-9 & 0.7528 & 0.9714 & 0.6970 & 0.9437 & 0.9375 & 1.0000 & & \\
\hline
\end{tabular}


According to Grubb (1971), Whitmore (1984), van Steenis (2006) and Kartawinata (2013), research locations are at an altitude of 765-915 m above sea level including the transition zone lowland rainforest and Sumatra's mountain rainforest. In contrast, according to Whitten et al. (1984), it is categorized into the lowland rainforest zone. From the results of vegetation analysis conducted at the Sipirok Botanic Gardens, species that often inhabit lowland rainforest, such as: Anthersma ghaesembilla, Carallia brachiata, Cryptocarya murrayi, and Pimelodendron macrocarpum can be found in remnant forest vegetation. Likewise, several species of Dipterocarpaceae which often inhabit lowland rainforest can still be found at the study site. Cyathea contaminans, which are often found in lower mountain forests (Whitten et al. 1984), are also found at the study site. According to Holttum (1963), C. contaminans spreads at an altitude of 200-1600 m above sea level. Based on the results of research Hanum et al. (2014), $C$. contaminans on Bali Island spreads at an altitude of 975$1930 \mathrm{~m}$ above sea level.

The Fagaceae and Lauraceae family which are often used to identify mountain forests (Whitten et al. 1984) can be found at the study site. However, the species found in the study plots generally have a broad distribution ranging from lowlands to mountains, such as Cinnamomum porrectum, Cinnamomum sintoc, Cryptocarya murrayi, and Persea americana (Lauraceae). Some species even inhabit lowland rainforests, such as Cinnamomum burmanni, Cinnamomum camphora, Litsea firma (Lauraceae), and Castanopsis motleyana (Fagaceae). In general, the species found at the study site came from both types of habitat with a wide distribution ranging from the lowlands to the mountains below (<2000 m asl), such as: Aglaia argentea, Arytera litoralis, Canthium glabrum, Dysoxylum alliaceum, Harpullia cupanioides, Macropanax undulatus, Meliosma simplicifolia, Syzygium papyraceum, and Turpinia sphaerocarpa.

Dacrycarpus imbricatus (Podocarpaceae) is one of the characteristics of mountain forests. This species is often found in tropical rainforests in a scattered pattern (scattered), and sometimes appears as a dominant species at an altitude of 800-2500 m above sea level. (Lemmens et al. 1995). On Mount Pangrango-West Java, D. imbricatus is found at an altitude of $1660 \mathrm{~m}$ above sea level (Yamada 1976). This species is also the dominant tree in the mountain forests of Bukit Raya in West Kalimantan, the Batukahu Nature Reserve in Bali, and Mount Ciremai in West Java (Kartawinata 2013). In the lower mountains where the 'Massenerhebung' effect can be found at lower altitudes such as Mount Silam-Sabah at an altitude of 540$790 \mathrm{~m}$ above sea level (Proctor et al. 1988). In the Dolok Sibual-buali Nature Reserve-North Sumatra, this species is found in the northern part which spreads at an altitude of 1300-1600 m above sea level (Anon 1993). Whitten et al. (1984) reported that D. imbricatus in Sumatra is commonly found in upper mountain forests. In the list of Sumatran orangutan forage plants (Onrizal 2011), D. imbricatus is a species that grows in the Batangtoru forest at an altitude of fewer than $1000 \mathrm{~m}$ above sea level. However, D. imbricatus is not found in the Sipirok Botanic Gardens.

Based on the altitude and analysis of the distribution of plant species at the study site, the Sipirok Botanic Gardens is in the ecoregion transition zone of the lowland rainforest and the Sumatran mountain rainforest. As a Botanic Gardens that will collect various species of forest plants, the potential number of plants that can be collected will be higher, especially those that live in lowland to lower mountain forests.

\section{ACKNOWLEDGEMENTS}

This research was funded by the South Tapanuli District Government, North Sumatra Province, Indonesia. Thank you to Abadi Siregar, Head of the Regional Planning Agency (Bappeda) of South Tapanuli District, Irwansah Harahap, Secretary of Bappeda, and South Tapanuli District Bappeda staff. Thank you also to Ikar Supriatna of the Bogor Botanic Gardens staff who helped carry out this research.

\section{REFERENCES}

Anon. 1993. Environmental Baseline Study of the Dolok Sibual-buali Nature Reserve Area. Pertamina-Unocal North Sumatra Geothermal Ltd. Indonesian Institute of Sciences, Bogor.

Barbour GM, Burk JK, Pitts WD. 1987. Terrestrial Plant Ecology. The Benyamin/Cummings Publishing Company, Inc. New York.

Gaines WL, Harrod JR, Lehmkuhl JF. 1999. Monitoring biodiversity: quantification and interpretation. General Technical Report PNWGTR-443, USDA Forest Service, Pacific North-West Research Station, Corvallis, OR.

Gillison AN, Liswanti N, Arief Rachman I. 1996. Rapid Ecological Assessment Kerinci Seblat National Park Buffer Zone. Report for Plant Ecology. Center For International Forestry Research (CIFOR) Working Paper No. 14. Cifor, Bogor.

Grubb PJ. 1971. Interpretation of the 'Massenerhebung' effect on tropical mountains. Nature 229: 44-45

Hammer Ø. 2014. PAST-Paleontological Statistics version 3.04. Natural History Museum, University of Oslo, Oslo, Norway. http://folk.uio.no/ohammer/past/.

Hanum SF, Hendriyani E, Kurniawan A. 2014. Distribution, population and habitat of tree ferns (Dicksonia spp. and Cyathea spp.) in Bali Island. Forest Rehabilitation Journal 2 (2): 111-122. [Indonesian]

Holttum RE. 1963. Cyatheaceae. Flora Malesiana Series II (1). WoltersNoordhoff Publishing, Groningen, The Netherlands.

IUCN. 2019. Shorea acuminata. The IUCN Red List of Threatened Species. Version 2019-2. https://www.iucnredlist.org/species/ 33921/68072072

Kartawinata K, Samsoedin I, Heriyanto M, Afriastini JJ. 2004. A tree species inventory in a one-hectare plot at the Batang Gadis National Park, North Sumatra, Indonesia. Reinwardtia 12 (2): 145-157.

Kartawinata K. 2013. Diversity of Indonesia's Natural Ecosystem. A short information with photos and pictures. LIPI Press-Yayasan Pustaka Obor Indonesia, Jakarta. [Indonesian]

Kendeigh SC. 1980. Ecology with Special Reference to Animal and Man. Prentice Hall of India Pvt. Ltd., New Delhi.

Kier G, Mutke J, Dinerstein E, Ricketts TH, Kuper W, Kreft H, Barthlott W. 2005. Global patterns of plant diversity and floristic knowledge. J. Biogeogr 32: 1-10. DOI: 10.1111/j.1365-2699.2005.01272.x

Kuswanda W, Barus SP. 2019. Characteristic and Diversity Vegetation of Bukit Tiga Puluh National Park as Dietary Sources for Reintroduced Sumatran Orang Utan (Pongo abelii Lesson). Bull Plasma Nutfah 25 (1): 53-66. 
Lemmens RHMJ, Soerianegara I, Wong WC (eds.). 1995. Plant Resources of Southeast Asia No 5 (2): Timber Trees Minor Commercial Timbers. Prosea, Bogor.

Ludwig JA, Reynold JF. 1988. Statistical ecology: a primer of methods and computing. Wiley Press, New York.

Magurran AE. 1988. Ecological Diversity and its Measurement. Croom Helm, London.

Mirmanto E, Sambas EN, Soedjito H. 1992. Fitosociology of Bengkulu forest. Proceedings of the Research and Development of Biological Resources 1991/1992. Puslitbang Biologi, LIPI: 174-182 [Indonesian]

Mueller-Dombois D, Ellenberg H. 1974. Aims and Methods of Vegetation Ecology. John Wiley \& Sons, New York.

Mutaqien Z, Zuhri M. 2011. Establishing a long-term permanent plot in remnant forest of Cibodas Botanic Garden, West Java. Biodiversitas 12 (4): 218-224.

Odum EP, Barrett GW. 2005. Fundamentals of Ecology. Thomson Brooks/Cole, Belmont, CA

Olson DM, Dinerstein E, Wikramanayake ED, Burgess ND, Powell GVN, Underwood EC, D`amico JA, Itoua I, Strand HE, Morrison JC, Loucks CJ, Allnutt TF, Ricketts TH, Kura Y, Lamoreux JF, Wettengel WW, Hedao P, Kassem KR. 2001. Terrestrial ecoregions of the world: a new map of life on earth. BioScience 15 (11): 933 938.

Onrizal. 2011. The potential trees for Sumatran orangutans for activities in the West and East Blocks of the Batang Toru Forest, specifically the Batang Toru Orangutan Corridor, North Sumatra Province. [Report] TFCA Sumatra Programme, Jakarta.

Priatna D, Kartawinata K, Abdulhadi R. 2006. Recovery of a lowland dipterocarp forest twenty-two years after selective logging at Sekundur, Gunung Leuser National Park, North Sumatra, Indonesia. Reinwardtia 12 (3): 237-255

Proctor J, Lee YF, Langley AM, Munro WRC, Nelson T. 1988 Ecological studies on Gunung Silam, a small ultrabasic mountain in Sabah, Malaysia. 1. Environment, forest structure and floristics. J Ecol 76 (2): 320-340.

Purnomo DW, Puspitaningtyas DM, Siregar M, Witono JR, Suhendar, Widoretno A, Lubis RF, Wahyuni S, Usmadi D, Supriatna I, Asnidar Y, Guswandi D, Suyanto, Riyono. 2018. Masterplan of Sipirok Botanic Garden, Tapanuli Selatan. [Final Report]. Center for Plant Conservation and Botanic Gardens, Indonesian Institute of Sciences, Bogor. [Indonesian]
Rahmah, Kartawinata K, Nisyawati, Wardhana W, Nurdin E. 2016. Tree species diversity in the lowland forest of the core zone of the Bukit Duabelas National Park, Jambi, Indonesia. Reinwardtia 15 (1): 11-26

Sambas EN, Siregar M. 1999. Flora composition of the forests of Mount Muncung, Singkep, Riau. The Botanic Gardens Bulletin 9 (1): 7-17. [Indonesian]

Sambas EN, Siregar M. 2004. Flora of Alas River Bank, Ketambe, Gunung Leuser National Park. BioSmart 6 (1): 33-38.

Samsoedin I, Heriyanto NM. 2010. Structure and composition of illegal logged-over forests in the Sei Lepan forest group, Sei Serdang, Gunung Leuser National Park, North Sumatera. Jurnal Penelitian Hutan dan Konservasi Alam 7 (3): 299-314. [Indonesian]

Smith RL. 1977. Element of ecology. Harper \& Row Publisher, New York.

Sugihartatmo, Maesuroh, Mantiri DMH, Witono JR, Purnomo DW, Mamonto P, Siregar M, Hasibuan P, Hadi A. 2017. Megawati Soekarnoputri Botanic Gardens: Journey towards the Creation of a Botanic Garden on Reclaimed Gold Mining Land in Ratatotok, Southeast Minahasa. Yayasan Pembangunan Berkelanjutan Sulawesi Utara (YPBSU). Jakarta.

Tothmeresz B. 2013. Diversity. University of Debrecen, Debrecen, Hungary.

van Steenis CGGJ. 2006. The Mountain Flora of Java. Brill, Leiden.

Whitmore, TC. 1984. Tropical Rainforest of the Far East. Clarendon Press, London.

Whitten AJ, Damanik SJ, Anwar J, Hisyam N. 1984. The Ecology of Sumatra. Gadjah Mada Univ. Press, Yogyakarta.

Witono JR, Purnomo DW, Usmadi D, Pribadi DO, Asikin D, Magandhi M, Sugiarti, Yuzammi. 2012. Indonesian Botanic Gardens Development Plan. Center for Plant Conservation and Botanic Gardens, Indonesian Institute of Sciences, Bogor. [Indonesian]

Witono JR, Usmadi D, Wihermanto, Purnomo DW, Safarinanugraha D, Pakiding Y, Netoseso N. 2020. Autecology of Drosera burmanni in the Wolobobo Botanic Gardens, Ngada District, Flores Island, $\begin{array}{llll}\text { Indonesia. Biodiversitas } 21 & (5): & 2137-2145 . & \text { DOI: }\end{array}$ 10.13057/biodiv/d210542.

Yamada I. 1976. Forest ecological studies of the montane forest of Mt. Pangrango, West Java. 1. Stratification and floristic composition of the montane rainforest near Cibodas. South East Asian Stud 13 (3): 402-426. 